Ike Rukmana Sari ${ }^{1}$ Anita M. Pasaribu ${ }^{2}$ Lena Manalu $^{3}$

\section{ANALISIS PENGARUH CURRENT RATIO, DEBT TO EQUITY , FIRM SIZE DAN KEPEMILIKAN MANAJERIAL TERHADAP PROFITABILITAS PADA PERUSAHAAN MANUFAKTUR SEKTOR BARANG KONSUMSI YANG TERDAFTAR DI BURSA EFEK INDONESIA TAHUN 2017-2019}

\begin{abstract}
Abstrak
Penelitian dilakukan guna mengetahui pengaruh, menganalisis, dan juga mendapatkan pemahaman apakah Current Ratio, Debt to Equity, Firm Size dan Kepemilikan Manajerial secara bersama-sama maupun individu berpengaruh terhadap Profitabilitas pada perusahaan Manufaktur sektor barang konsumsi yang terdaftar di Bursa Efek Indonesia tahun 2017-2019. Pendekatan Kuantitatif ialah pendekatan yang dipakai dalam penelitian kami. Penelitian asosiatif merupakan jenis penelitian yang kami pakai dalam riset ini, sebab meneliti hubungan atau pengaruh data. Regresi Linear adalah metode yang digunakan peneliti untuk menganalisis hasil dari penelitian kami. Ada 51 populasi perusahaan manufaktur sektor barang konsumsi tahun 2017-2019 dengan sampel sebanyak 72 perusahaan manufaktur sektor barang konsumsi periode 2017-2019. Variabel pada penelitian ini juga mempengaruhi variabel independen, Current Ratio, Debt to equity, Firm size dan Kepemilikan Manajerial berpengaruh terhadap profitabilitas pada perusahaan manufaktur sektor barang konsumsi yang terdaftar di Bursa Efek Indonesia periode 2017-2019. Dari hasil pengujian dapat diketahui besaran nilai $R$ square $\left(\mathrm{R}^{2}\right)$ sebesar 0,049 atau bernilai 0,49\%. Penelitian dicoba dengan tata cara metode regresi linear berganda serta hipotesis uji memakai proses SPSS 26.
\end{abstract}

Kata Kunci: Current Ratio, Debt to Equity, Firm Size dan Kepemilikan Manajerial

\begin{abstract}
Research was conducted to determine the influence, analyze, and also get an understanding of whether current ratio, debt to equity, firm size and managerial ownership together and individuals affect profitability in manufacturing companies in the consumer goods sector listed on the Indonesia Stock Exchange in 2017-2019. Quantitative Approach is the approach used in our research. Associative research is a type of research that we use in this research, because it examines the relationship or influence of data. Linear Regression is a method that researchers use to analyze the results of our research. There were 51 populations of consumer goods manufacturing companies in 2017-2019 with a sample of 72 manufacturing companies in the consumer goods sector in the period 2017-2019. The variables in this study also affect independent variables, Current Ratio, Debt to equity, Firm size and Managerial Ownership affect profitability in consumer goods sector manufacturing companies listed on the Indonesia Stock Exchange for the period 2017-2019. From the test results can be known the amount of R square (R2) value of 0.049 or worth $0,49 \%$. The research was conducted by multiple linear regression methods as well as test hypotheses using SPSS 26 process.
\end{abstract}

Keywords: Current Ratio, Debt to Equity, Firm Size and Managerial Ownership PENDAHULUAN

Perusahaan sektor industri barang konsumsi yang terdaftar di Bursa Efek Indonesia (BEI) merupakan salah satu subbagian dari sektor manukfaktur. Dalam pelaksanaanya sektor barang

\footnotetext{
1,2,3) Prodi S1 Akuntansi, Fakultas Ekonomi, Universitas Prima Indonesia Alamat $e$-mail: anitamagdalena752@gmail.com,ikerukmana@gmail.com
} 
konsumsi terbagi atas lima macam subsektor yaitu subsektor industry makanan dan minuman, subsector rokok, subsektor farmasi, subsektor kosmetik dan keperluan rumah tangga.

Persaingan dalam dunia usaha khususnya pada usaha industri barang konsumsi membuat setiap perusahaan semakin meningkatkan kinerja agar tujuannya tercapai. Pada umumnya Perusahaan didirikan dengan tujuan meningkatkan profitabilitas sehingga dapat memberikan kemakmuran bagi pemilik atau pemegang saham, profitabilitas dapat ditujukan dengan melihat kemampuan perusahaan untuk memperoleh laba yang maksimal.

Current Ratio dianggap sebagai salah satu rasio keuangan dalam menyelesaikan kewajiban jangka pendeknya dimana dengan menggunakan aktiva lancar yang dimiliki dapat mempengaruhi perkembangan profitabilitas perusahaan. Semakin tinggi current ratio yang dihasilkan semakin besar pula kemampuan perusahaan dalam membayar kewajiban jangka pendeknya. Debt to equity ratio (DER) juga menjadi tolak ukur yang digunakan untuk menilai hutang dengan ekuitas. rasio der akan berpengaruh terhadap nilai perusahaan dimana investor akan memilih nilai DER yang tinggi karena menunjukan kecilnya risiko keuangan yang ditanggung perusahaan. Debt To Equity Ratio (DER) merupakan rasio yang digunakan untuk menilai hutang dengan ekuitas.

Firm Size menjadi salah satu variabel yang dipertimbangkan dalam menentukan nilai suatu perusahaan. Perusahaan ini dikategorikan perusahaan berskala besar dan perusahaan berskala kecil. Firm Size merupakan cerminan total dari aset yang dimiliki suatu perusahaan. Perusahaan yang berskala besar menunjukan perusahaan sedang bertumbuh sehingga mempengaruhi profitabilitas perusahaan, profit yang meningkat cenderung akan menarik minat investor yang kemudian membuat permintaan saham perusahaan meningkat, sehingga harga saham perusahaan menjadi melambung tinggi yang menghasilkan tingginya nilai perusahaan, maka dapat dikatakan bahwa besar kecilnya ukuran suatu perusahaan secara langsung berpengaruh terhadap profitabilitas dari perusahaan tersebut.

Kepemilikan manajerial turut mempengaruhi profitabilitas perusahaan karena dapat dipercaya mampu mepengaruhi operasional perusahaan yang pada akhirnya berpengaruh pada kinerj perusahaan dalam mencapai tujuan peusahaan.

Berdasarkan data yang diperoleh dari www.idx.co.id, pada tahun 2019 total hutang PT. Indofood Sukses Makmur Tbk (INDF) 41.996.071, menunjukkan bahwa adanya penurunan dibanding pada tahun 2018.Dimana pada tahun 2018 total hutang 46.620.996. Total hutang yang meningkat dapat menurunkan profitabilitas namun kenyataannya total hutang meningkat justru profitablitas meningkat.

Pada tahun 2019 ,total ekuitas PT. Indofood Sukses Makmur Tbk (INDF) 96.198.559 menunjukkan adanya penurunan dibanding pada tahun 2018 dengan total 96.537.796. Hal ini terjadi karena pada tahun 2019 total beban juga mengalami penurunan dengan total 41.996.071 dibandingkan pada tahun 2018 dengan total 46.620 .996 dengan terjadinya penurunan beban akan mempengaruhi ekuitas dan dengan meningkatnya beban akan membuat ekuitas semakin terbatas. Pada tahun 2019 terjadi peningkatan profitabilitas dengan total 6.588 .662 dibanding pada tahun 2018 dengan total 6.350 .788 peningkatan terjadi dimana current ratio sebagai pengukur kinerja keuangan pada tahun 2019 ada diangka 1,272 dan pada tahun 2018 current ratio 1,066 . Total ekuitas yang menurun dapat menurunkan profitabilitas namun kenyataannnya justru meningkatkan profitabilitas.

Peneliti melakukan penelitian di Perusahaan Manufaktur sektor barang konsumsi dimana perusahaan ini memiliki berbagai peranan penting dalam perekonomian. Di antara peranan tersebut yang paling menonjol yaitu di dalam skala nasional sektor ini memberikan sumbangsih berupa peningkatan perekonomian.

Berdasarkan uraian dan fenomena diatas ,maka peneliti tertarik melakukan penelitian dengan judul : "Analisis Pengaruh Current Ratio, Debt to Equity, Firm Size dan Kepemilikan Modal Terhadap Profitabilitas pada Perusahaan Manufaktur Sektor Barang Konsumsi yang Terdaftar di Bursa Efek Indonesia Tahun 2017-2019."

\section{METODE}

Menurut Sugiyono (2013: 13), "metode penelitian kuantitatif dapat diartikan sebagai metode penelitian yang berlandaskan pada filsafat positivisme, digunakan untuk meneliti pada populasi 
atau sampel tertentu, teknik pengambilan sampel pada umumnya dilakukan secara random, pengumpulan data menggunakan instrumen penelitian, analisis data bersifat kuantitatif/statistik dengan tujuan untuk menguji hipotesis yang telah ditetapkan. Penelitian ini menggunakan pendekatan deskriptif dengan tujuan untuk mendeskripsikan objek penelitian atupun hasil penelitian." Adapun pengertian deskriptif menurut Sugiyono (2012: 29) adalah "metode yang berfungsi untuk mendeskripsikan atau memberi gambaran terhadap objek yang diteliti melalui data atau sampel yang telah terkumpul sebagimana adanya, tanpa melakukun analisis dan membuat kesimpulan yang berlaku umum."

\section{HASIL DAN PEMBAHASAN}

\section{Hasil Penelitian}

\subsection{Gambaran Umum Bursa Efek Indonesia}

Bursa Efek Indonesia atau disingkat BEI merupakan bursa saham di Indonesia yang memfasilitasi perdagangan saham, pendapatan tetap, instrumen derivatif, reksadana, saham hingga obligasi yang berbasis Syariah. BEI juga menyediakan data perdagangan real time dalam data-feed format untuk vendor data atau perusahaan. BEI memberikan informasi yang lebih lengkap tentang perkembangan bursa kepada publik. BEI menyebarkan data pergerakan harga saham melalui media cetak dan elektronik. Satu indikator yang menyebabkan pergerakan harga saham tersebut adalah indeks harga saham. Hingga saat ini Indonesia memiliki Bursa Efek Indonesia yang merupakan penggabungan Bursa Efek Surabaya (BES) ke Bursa Efek Jakarta (BEJ) pada tahun 2007. Pada 2 Maret 2009 diadakannya peluncuran perdana sistem perdagangan baru PT Bursa Efek Indonesia: JATS-NextG (Sumber: www.idx.co.id diakses pada Sabtu 5 Juni 2021).

Khususnya dalam penelitian ini, penelitian dilaksanakan pada perusahaan sektor industri barang konsumsi yang terdaftar di Bursa Efek Indonesia (BEI) merupakan salah satu subbagian dari sektor manukfaktur periode tahun 2017-2019. Dalam pelaksanaanya sektor barang konsumsi terbagi atas lima macam subsektor yaitu subsektor industri makanan dan minuman, subsektor rokok, subsektor farmasi, subsektor kosmetik dan keperluan rumah tangga.

\subsection{Statistik Deskriptif}

Guna mengetahui nilai minimun, maksimum, mean, dan standard deviasi pada pemilihan skor angket oleh responden dalam penelitian ini, maka dapat dilihat sebagai berikut:

\section{Tabel 1 Uji Deskriptif Descriptive Statistics}

\begin{tabular}{l|r|r|r|r|r} 
& N & Minimum & Maximum & Mean & Std. Deviation \\
\hline Kepercayaan & 72 & 2 & 5 & 3.71 & 1.035 \\
\hline Produk & 72 & 2 & 5 & 3.93 & .966 \\
\hline Layanan & 72 & 2 & 5 & 3.78 & 1.011 \\
\hline Minat & 72 & 3 & 5 & 4.15 & .632 \\
\hline Valid N (listwise) & 72 & & & & \\
\hline
\end{tabular}

\subsection{Uji Asumsi Klasik}

\subsection{Uji Normalitas}

Penelitian ini dalam melakukan uji normalitas menggunakan model KolmogorovSmirnov. Model regresi variable pengganggu atau residual distribusi normal atau tidak tujuan uji normalitas ini. Cara untuk mendeteksi apakah residual terdistribusi secara normal atau tidak adalah dengan analisis grafik atau analisis statistik (Ghazali, 2016:160).

Pengujian residual analisis statistik adalah dengan uji statistic non parametik Kolmogorov-Smirnov (K-S). Apabila hasil uji K-S menunjukkan bahwa Assym. Sig. (2tailed) lebih dari 0,05 maka residual terdistribusi secara normal. Sebaliknya jika hasil 
uji tersebut menunjukkan bahwa Assymp. Sig. (2-tailed) kurang dari 0,05 maka residual tidak terdistribusi secara normal.

Tabel. 2 Uji Normalitas Data

One-Sample Kolmogorov-Smirnov Test

\begin{tabular}{|ll|r|}
\hline & & $\begin{array}{c}\text { Unstandardized } \\
\text { Residual }\end{array}$ \\
\hline $\mathrm{N}$ & Mean & 72 \\
Normal Parameters & 0 \\
& Std. & 3872.565121 \\
& Deviation & 0.435 \\
Most Extreme & Absolute & 0.435 \\
Differences & Positive & -0.404 \\
& Negative & 0.435 \\
Test Statistic & & $.067^{\mathrm{c}}$ \\
Asymp. Sig. (2-tailed) & & \\
\hline
\end{tabular}

a. Test distribution is Normal.

b. Calculated from data.

c. Lilliefors Significance Correction.

Dari hasil pengujian tersebut, dapat diketahui nilai asymp. Sig. (2-tailed) sebesar 0,067. Sesuai dengan kreiteria apabila hasil uji K-S menunjukkan bahwa Assym. Sig. (2tailed) lebih dari 0,05 maka residual terdistribusi secara normal. Sebaliknya jika hasil uji tersebut menunjukkan bahwa Assymp. Sig. (2-tailed) kurang dari 0,05 maka residual tidak terdistribusi secara normal.

Maka dapat diketahui nilai asymp. Sig. (2-tailed) sebesar 0,067>0,05 maka residual terdistribusi secara normal. Sehingga, uji normalitas dengan menggunakan uji kolmogrov-smirnov dinyatakan data terdistribusi secara normal, dan memenuhi syarat uji asumsi klasik. Selain uji normalitas menggunakan Kolmogorov_Smirnov, peneliti juga memakai analisis histogram serta normal probability plot. Berikut tampilan histrogram:

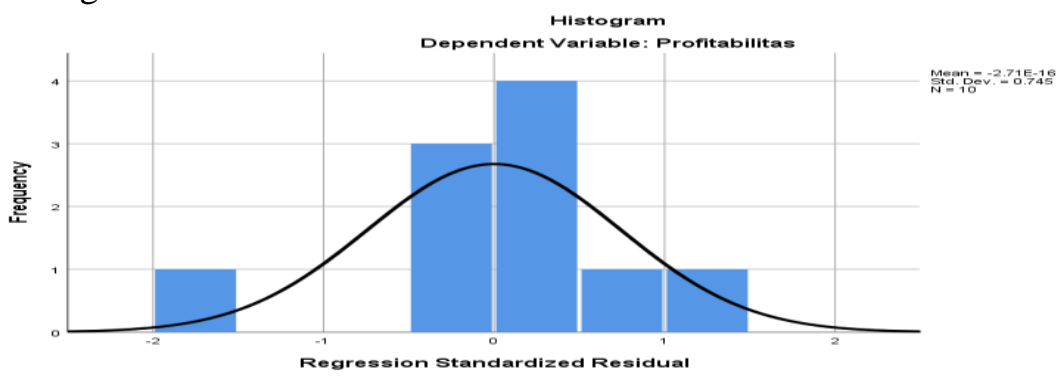

Gambar 1 Uji Normalitas Data Histogram

Pada Gambar diatas, grafik histogram sesudah dilakukan Ln, dapat dilihat data telah berdistribusi secara normal sebab grafik histogram menunjukkan pola distribusi yang tidak miring ke kiri dan ke kanan. Dapat dilihat juga garis diagonal membagi sama rata dua sisi secara simetris terhadap histogram maka diambil kesimpulan data berdistribusi normal. Disamping grafik histogram digunakan untuk menentukan data berdistribusi normal, dapat melihat dari normalitas probability plot pada gambar berikut: 


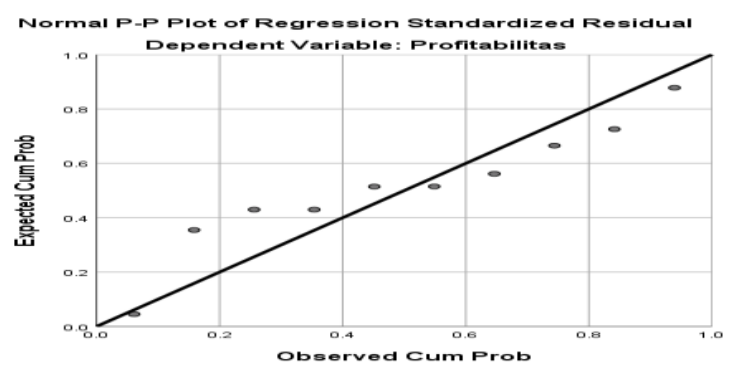

Gambar 2 Uji Normalitas Data P-P Plot

Pada Gambar diatas, Grafik normalitas probability plot sesudah dilakukan Ln, menunjukkan titik-titik berada diantara garis diagonal mengikuti garis. Dapat ditarik kesimpulan bahwa grafik 12probability plot tersebut berdistribusi secara normal. Dengan demikian, data telah berdistribusi normal karena hasil uji normalitas, grafik histogram, P-P Plot dan Kolmogorov_Smirnov telah memenuhi syarat asumsi normal.

\subsection{Uji Multikolinieritas}

Uji multikolinieritas digunakan sebagai salah satu syarat dalam uji asumsi klasik. Bila mana tidak dijumpai multikolinieritas maka tahapan dalam penelitian model regresi dapat dilanjutkan. Bertujuan untuk menguji apakah model regresi ditemukan adanya korelasi antara variabel bebas. Model regresi yang baik seharusnya tidak terjadi korelasi antara variabel independent (Ghazali, 2016:105). Dasar pengambilan keputusan dalam uji ini dengan menggunakan uji beda nilai tolerance dan VIF, "menurut Imam Ghazali tidak terjadi gelaja multikolineritas jika nilai tolerance $>0,100$ dan nilai $\mathrm{VIF}<10,00$."

Tabel 3 Uji Multikolinieritas

\section{Coefficients $^{\mathbf{a}}$}

Standardized

Unstandardized Coefficients Coefficients

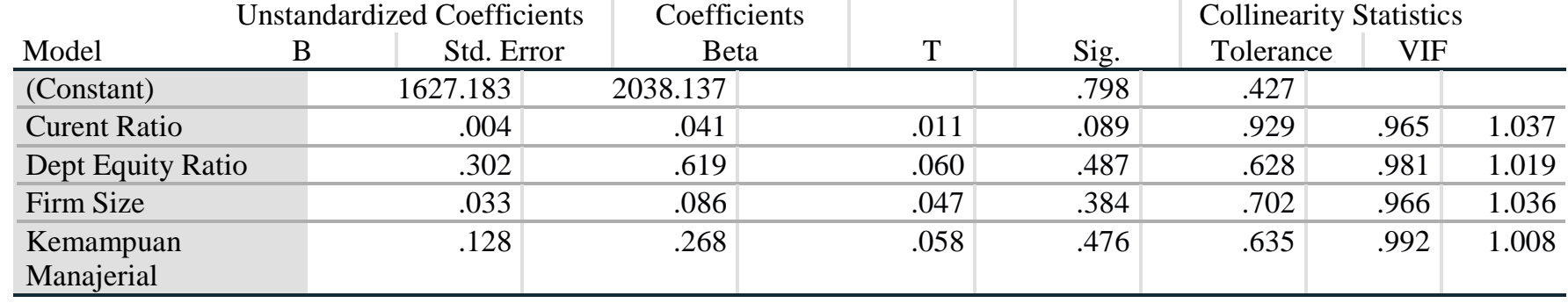

a. Dependent Variable: Profitabilitas

Dari tabel tersebut dapat diketahui Interpretasi pengambilan nilai:

1. Variabel Curent Ratio nilai tolerance sebesar 0,965 > 0,100 dan nilai VIF sebesar 1,037 $<0,10$ artinya tidak terjadi gelaja multikolineritas.

2. Variabel Dept Equity Ratio nilai tolerance sebesar 0,981 >0,100 dan nilai VIF sebesar $1,019<0,100$ artinya tidak terjadi gelaja multikolineritas.

3. Variabel Firm Size nilai tolerance sebesar 0,966 > 0,100 dan nilai VIF sebesar 1,036 < 0,100 artinya tidak terjadi gelaja multikolineritas.

4. Variabel Kemampuan Manajerial nilai tolerance sebesar 0,992 > 0,100 dan nilai VIF sebesar $1,008<0,100$ artinya tidak terjadi gelaja multikolineritas.

Dari hasil pengujian dari ketiga variabel independen dalam penelitian ini semuanya dinyatakan memenuhi kriteria dan tidak ditemukan adanya gejala multikolinieritas sehingga dapat melanjutkan kepada tahapan selanjutnya.

\subsection{Uji Autokorelasi}

Penelitian ini, menggunakan uji autokorelasi menggunakan model Durbin and Watson. Menurut imam ghazali "suatu uji auotokorelasi dapat dikatakan tidak ada gejela autokorelasi jika nilainya terletak diantara du sampai dengan (4-du). Uji Durbin Waston (uji DW) hanya digunakan untuk autokorelasi tingkat satu (first other autocorrelation) dan tidak ada variabel lagi di antara variabel independen (Ghazali, 2016:111)" 


\begin{tabular}{|c|c|c|c|c|c|}
\hline \multicolumn{6}{|c|}{$\begin{array}{l}\text { Tabel } 4 \text { Uji Autokorelasi } \\
\text { Model Summary }^{\text {b }}\end{array}$} \\
\hline Model & $\mathrm{R}$ & R Square & $\begin{array}{l}\text { Adjusted R } \\
\text { Square }\end{array}$ & $\begin{array}{l}\text { Std. Error of the } \\
\text { Estimate }\end{array}$ & Durbin-Watson \\
\hline 1 & $.099^{\mathrm{a}}$ & .010 & .04 & 3986.48838 & 2.039 \\
\hline
\end{tabular}

Dari hasil penghitungan tersebut didapatkan nilai durbin-watson sebesar 2,039. Kemudian untuk mencari nilai du dicari pada diitribusi tabel durbin-watson, berdasarkan K (4) dan N (72) dengan nilainya yaitu 1,340 , dengan menggunakan rumus $4-\mathrm{du}(1,340)=3,340$.

Dengan menggunakan dasar pengambilan keputusan kriteria tidak ada gejala auto korelasi jika nilai durbin-watson terletak antara du sampai dengan (4-du), 1,340 (nilai du) > 2,039 (nilai durbin-watson) $>$ 3,340 (nilai 4-du). Nilai uji autokorelasi berada diantara nilai du dan (4-du) sehingga dapat dikatakan tidak ada gejala auto korelasi dalam penelitian ini, dan dinyatakan memenuhi syarat uji asumsi klasik.

\subsection{Uji Heterokedastisitas}

Penelitian ini dalam melakukan uji heteroskedastisitas menggunakan model scater. Uji heteroskedastisitas bertujuan untuk menguji apakah dalam model regresi terjadi ketidak samaan varians dari residual satu pengamatan ke pengamatan yang lain. Jika varians dari residual satu pengamatan ke pengamatan tetap maka disebut homokedastistisitas dan jika berbeda heteroskedastisitas.

"Model regresi yang baik adalah yang homokesdastisitas atau tidak terjadi heteroskedastisitas (Ghazali, 2016:139)." Untuk mendeteksi adanya gejala heteroskedastisitas, akan digunakan uji Glejser. Metode ini dilakukan dengan meregresikan variabel bebasnya terhadap nilai absolute residual. Metode regresi tidak mengandung heteroskedastisitas apabila nilai signifikan variabel bebasnya terhadap nilai absolute residual statistik lebih besar dari $\alpha=$ 0,05 .

\section{Tabel 5 Uji Heteroskedastisitas}

\begin{tabular}{|c|c|c|c|c|c|c|}
\hline \multicolumn{7}{|c|}{ ANOVA $^{a}$} \\
\hline Model & & Sum of Squares & Df & Mean Square & F & Sig. \\
\hline \multirow[t]{3}{*}{1} & Regression & .000 & 4 & .000 & .000 & $.230^{\mathrm{b}}$ \\
\hline & Residual & $\begin{array}{r}1064770003.54 \\
2\end{array}$ & 67 & 15892089.605 & & \\
\hline & Total & $\begin{array}{r}1064770003.54 \\
2\end{array}$ & 71 & & & \\
\hline
\end{tabular}

a. Dependent Variable: Abs_RES

b. Predictors: (Constant), Kemampuan Manajerial, Dept Equity Ratio, Firm Size, Curent Ratio

Sesuai dengan uji statistik tersebut, dapat diketahui jika uji hetrerokedastisitas model regresi dengan uji glejser sebesar 0,230 . Sesuai dengan kriteria apabila nilai signifikan variabel bebasnya terhadap nilai absolute residual statistik lebih besar dari $\alpha=0,05$. Kesimpulannya $0,230>0,05$ maka dapat diartikan jika tidak ada gejala heteroskedastisitas sehingga syarat asumsi klasik dalam uji regresi berganda dapat terpenuhi.

Selain itu, guna mengevaluasi suatu model regresi dimana terdapat varians tidak merata antara residual pengamatan model dengan observasi lainnya maka peneliti melakukan uji heterokedastisitas. Apabila variance variabel penganggu antar pengatan berbeda, maka dikatakan heterokedastisitas. Suatu penelitian harus dapat mempertahankan homokedastisitas dan tidak terjadi heterokedastisitas dalam model regresinya. Pengambilan keputusan dilakukan dengan mengamati grafik scatterplott berikut : 


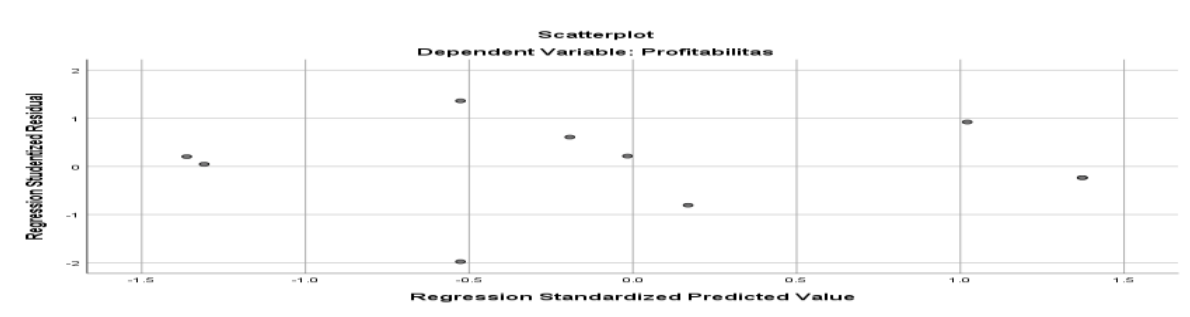

\section{Gambar 3 Uji Heterokedastistitas Scatterplot}

Pada gambar diatas sesudah dilakukan Ln, menunjukkan data pada penelitian ini tersebar secara acak diantara garis 0 yang dapat ditarik kesimpulan pada penelitian yang telah dilakukan tidak terdapat heterokedastisitas.

\section{Hasil Analisis Data}

\section{III.3.1. Analisis Regresi Linier}

Uji regresi linier berganda dilakukan untuk mengetahui seberapa besar pengaruh variabel independen atau variabel bebas yaitu Tabel tersebut dapat diketahui nilai Curent Ratio (X1), Dept Equity Ratio (X2), Firm Size (X3), Kemampuan Manajerial (X4), dan Profitabilitas (Y).

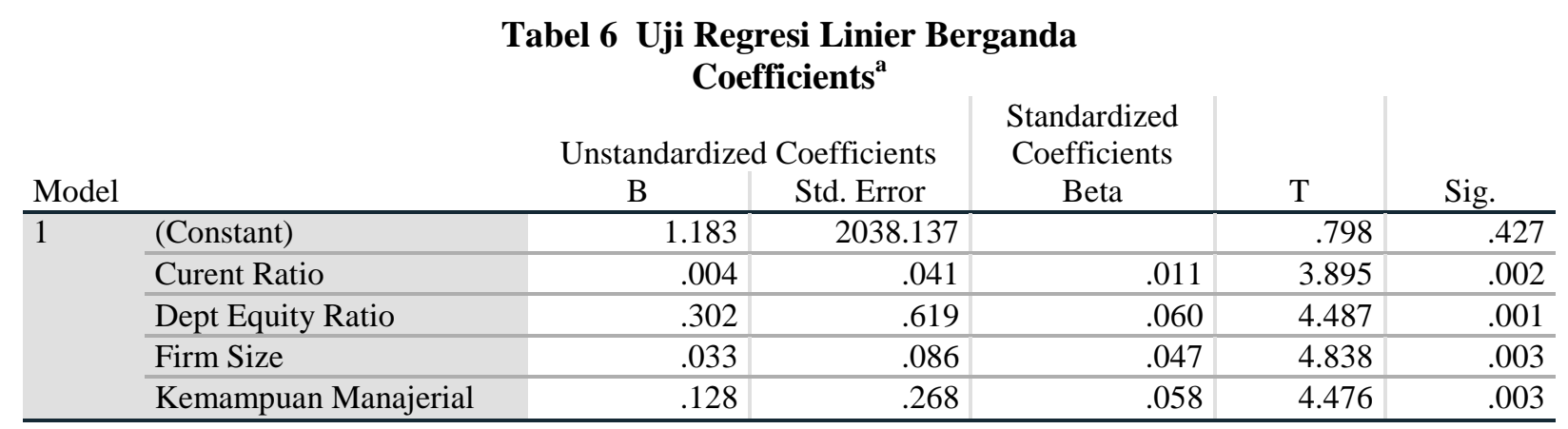

a. Dependent Variable: Profitabilitas

Berdasarkan pada tabel 4.8 diatas, maka dapat disusun persamaan atau model regresi sebagai berikut:

$\mathrm{Y}=1,183+0,004 \mathrm{X}_{1}+0,302 \mathrm{X}_{2}+0,033 \mathrm{X}_{3}+0,128 \mathrm{X}_{4}+e$

Dari persamaan regresi diatas, maka dapat diuraikan sebagai berikut:

Konstanta sebesar 1,183 diketahui nilai Curent Ratio (X1), Dept Equity Ratio (X2), Firm Size (X3), Kemampuan Manajerial (X4), dan Profitabilitas (Y), nilainnya sebesar 1,183.

a. Koefisien Curent Ratio $\left(\mathrm{X}_{1}\right)$ sebesar 0,004 artinya bahwa setiap kenaikan satu satuan Curent Ratio $\left(\mathrm{X}_{1}\right)$, akan meningkatkan Profitabilitas sebesar 0,004 satuan.

b. Koefisien Dept Equity Ratio $\left(\mathrm{X}_{2}\right)$ sebesar 0,302 artinya bahwa setiap kenaikan satu satuan Dept Equity Ratio $\left(\mathrm{X}_{2}\right)$, akan meningkatkan Profitabilitas sebesar 0,302 satuan.

c. Koefisien Firm Size $\left(\mathrm{X}_{3}\right)$, sebesar 0,033 artinya bahwa setiap kenaikan satu satuan Firm Size $\left(\mathrm{X}_{3}\right)$, akan meningkatkan Profitabilitas sebesar 0,033 satuan.

d. Koefisien Kemampuan Manajerial $\left(\mathrm{X}_{4}\right)$ sebesar 0,128 artinya bahwa setiap kenaikan satu satuan Kemampuan Manajerial $\left(\mathrm{X}_{4}\right)$, akan meningkatkan Profitabilitas sebesar 0,128 satuan.

3.2. Koefisien Determinasi $(R 2)$

Dalam penelitian ini, guna mengetahui sebesara besar pengaruh variabel independen terhadap variabel dependen maka digunakan uji $R$ square. 
Tabel 7 Koefisien Determinasi (R2)

(Sesudah Ln)

Model Summary ${ }^{\mathrm{b}}$

\begin{tabular}{|c|c|c|c|c|c|}
\hline \multicolumn{6}{|c|}{ Model Summary } \\
\hline Model & $\mathrm{R}$ & R Square & $\begin{array}{l}\text { Adjusted R } \\
\text { Square }\end{array}$ & $\begin{array}{l}\text { Std. Error of } \\
\text { the Estimate }\end{array}$ & $\begin{array}{l}\text { Durbin- } \\
\text { Watson }\end{array}$ \\
\hline 1 & $.099^{\mathrm{a}}$ & .706 & .049 & 3986.48838 & 2.039 \\
\hline
\end{tabular}

a. Predictors: (Constant), Kemampuan Manajerial, Dept Equity Ratio, Firm Size,

Curent Ratio

b. Dependent Variable: Profitabilitas

Dari hasil pengujian tersebut dapat diketahui besaran nilai $R$ square $\left(\mathrm{R}^{2}\right)$ sebesar 0,049 atau jika dikonfersi menuju persen menjadi $0,49 \%$. Sehingga dapat ditarik kesimpulan jika pengaruh Curent Ratio (X1), Dept Equity Ratio (X2), Firm Size (X3), Kemampuan Manajerial (X4), terhadap Profitabilitas (Y) yaitu sebesar 4,9\%, selebihnya dipengaruhi oleh variabel lain yang tidak diteliti dalam penelitian ini.

\section{III.3.3. Pengujian Hipotesis secara Simultan (Uji F)}

Uji ini digunakan untuk mengetahui pengaruh dari suatu variabel independen secara bersama-sama terhadap variabel dependen. Menurut Imam Ghazali (2011: 101), jika nilai sig. < 0,05 maka variabel $\mathrm{X}$ berpengaruh terhadap Y. Selain itu guna meyakinkan hasil penelitian, dilakukan perbandingan pada nilai hitung $\mathrm{f}$ tabel, jika nilai $\mathrm{f}$ hitng $>\mathrm{f}$ tabel maka variabel $\mathrm{X}$ beprngaruh terhadap Y.

\begin{tabular}{|c|c|c|c|c|c|c|}
\hline \multirow[b]{2}{*}{ Model } & \multicolumn{6}{|c|}{$\begin{array}{c}\text { Tabel } 8 \text { Hipotesa F Simultan } \\
\text { (Sesudah Ln) } \\
\text { ANOVA }^{\mathrm{a}}\end{array}$} \\
\hline & & $\begin{array}{l}\text { Sum of } \\
\text { Squares }\end{array}$ & Df & Mean Square & F & Sig. \\
\hline 1 & Regression & 10435631.069 & 4 & 2608907.767 & 5.164 & $.004^{\mathrm{b}}$ \\
\hline & Residual & $\begin{array}{r}1064770003.5 \\
42\end{array}$ & 67 & 15892089.605 & & \\
\hline & Total & $\begin{array}{r}1075205634.6 \\
11\end{array}$ & 71 & & & \\
\hline
\end{tabular}

a. Dependent Variable: Profitabilitas

b. Predictors: (Constant), Kemampuan Manajerial, Dept Equity Ratio, Firm Size, Curent Ratio

Dari hasil pengujian tersebut dapat diketahui, jika nilai sig. $<0,05$ maka variabel $\mathrm{X}$ berpengaruh terhadap Y. Maka dapat diketahui $0.004<0,05$ sehingga dari perbandingan pada uji signifikansi dapat dinyatakan hipotesa diterima.

3.4. Pengujian Hipotesis secara Parsial (Uji t)

Uji ini digunakan dalam penelitian model regresi dengan menguji antara satu variabel independen dengan variabel dependen. Dengan analisis berdasarkan perbandingan nilai signifikansi. Menurut imam gazhali (2011:101), jika nilai sig. < 0,05 maka artinya variabel X berpengarhuh terhadap variabel $\mathrm{Y}$, atau penghitungan uji $T$ Parsial berdasarkan $\mathrm{t}$ hitung dan $\mathrm{t}$ tabel, jika niali t hitung $>\mathrm{t}$ tabel berpengaruh.

Rumus mencari t tabeL yaitu $(0,05: 2 ; \mathrm{n}-\mathrm{k}-1)=0,025 ; 72-4-1=0,025 ; 67=2,144$.

Mengacu dari hipotesis tersebut, maka hasil pengujian statistik yang dilaksanakan yaitu sebagai berikut: 


\section{Tabel 9 Uji t Parsial}

Coefficients $^{\mathrm{a}}$

\begin{tabular}{|c|c|c|c|c|c|c|}
\hline \multirow{2}{*}{\multicolumn{2}{|c|}{ Model }} & \multicolumn{2}{|c|}{ Unstandardized Coefficients } & \multirow{2}{*}{$\begin{array}{c}\text { Standardized } \\
\text { Coefficients } \\
\text { Beta }\end{array}$} & \multirow[b]{2}{*}{$\mathrm{T}$} & \multirow[b]{2}{*}{ Sig. } \\
\hline & & $\mathrm{B}$ & Std. Error & & & \\
\hline \multirow[t]{5}{*}{1} & (Constant) & 1.183 & 2038.137 & & .798 & .427 \\
\hline & Curent Ratio & .004 & .041 & .011 & 3.895 & .002 \\
\hline & Dept Equity Ratio & .302 & .619 & .060 & 4.487 & .001 \\
\hline & Firm Size & .033 & .086 & .047 & 4.838 & .003 \\
\hline & Kemampuan Manajerial & .128 & .268 & .058 & 4.476 & .003 \\
\hline
\end{tabular}

a. Dependent Variable: Profitabilitas

Maka interpretasi dalam penelitian ini, sebagai berikut:

$\mathrm{H}_{1}$ : Current Ratio berpengaruh secara parsial terhadap profitabilitas pada perusahaan manufaktur sektor barang konsumsi yang terdaftar di Bursa Efek Indonesia periode 2017-2019

Sesuai dengan penghitungan dapat diketahui nilai signifikansi sebesar 0,002. Sesuai dengan jika nilai sig. $<0,05$ maka artinya variabel $\mathrm{X}$ berpengarhuh terhadap variabel $\mathrm{Y}, 0,002<0,05$ maka dapat dikatakan pada hipotesa yang pertama variabel $\mathrm{X} 1$ berpengaruh terhadap variabel Y. Kesimpulannya Hipotesa pertama dalam penelitian ini diterima.

$\mathrm{H}_{2}$ : Debt To Eqiuty berpengaruh secara parsial terhadap profitabilitas pada perusahaan manufaktur sektor barang konsumsi yang terdaftar di Bursa Efek Indonesia periode 2017-2019

Sesuai dengan penghitungan dapat diketahui nilai signifikansi sebesar 0,001. Sesuai dengan jika nilai sig. $<0,05$ maka artinya variabel $\mathrm{X}$ berpengarhuh terhadap variabel $\mathrm{Y}, 0,001<0,05$ maka dapat dikatakan pada hipotesa yang pertama variabel $\mathrm{X} 2$ berpengaruh terhadap variabel Y. Kesimpulannya Hipotesa kedua dalam penelitian ini diterima.

$\mathrm{H}_{3}$ : Firm Size berpengaruh secara parsial terhadap profitabilitas pada perusahaan manufaktur sektor barang konsumsi yang terdaftar di Bursa Efek Indonesia periode 2017-2019

Sesuai dengan penghitungan dapat diketahui nilai signifikansi sebesar 0,003 . Sesuai dengan jika nilai sig. $<0,05$ maka artinya variabel $\mathrm{X}$ berpengarhuh terhadap variabel $\mathrm{Y}, 0,003<0,05$ maka dapat dikatakan pada hipotesa yang pertama variabel $\mathrm{X} 2$ berpengaruh terhadap variabel Y. Kesimpulannya Hipotesa ketiga dalam penelitian ini diterima.

$\mathrm{H}_{4}$ : Kepemilikan Manajerial berpengaruh secara parsial terhadap profitabilitas pada perusahaan manufaktur sektor barang konsumsi yang terdaftar di Bursa Efek Indonesia periode 2017-2019

Sesuai dengan penghitungan dapat diketahui nilai signifikansi sebesar 0,003. Sesuai dengan jika nilai sig. $<0,05$ maka artinya variabel $\mathrm{X}$ berpengarhuh terhadap variabel $\mathrm{Y}, 0,003<0,05$ maka dapat dikatakan pada hipotesa yang pertama variabel $\mathrm{X} 2$ berpengaruh terhadap variabel Y. Kesimpulannya Hipotesa keempat dalam penelitian ini diterima.

\section{SIMPULAN}

Sesuai dengan hasil penelitian ini dapat disimpulkan, bahwasanya:

1. Current Ratio berpengaruh secara parsial terhadap profitabilitas pada perusahaan manufaktur sektor barang konsumsi yang terdaftar di Bursa Efek Indonesia periode 2017-2019. Sesuai pengujian t parsial menunjukkan nilai signifikansi $0,002<0,05$ dan nilai thitung 3,895 > 2,144, yang dapat dikatakan memberikan pengaruh.

2. Debt To Eqiuty berpengaruh secara parsial terhadap profitabilitas pada perusahaan manufaktur sektor barang konsumsi yang terdaftar di Bursa Efek Indonesia periode 2017-2019. Sesuai pengujian t parsial menunjukkan nilai signifikansi $0,001<0,05$ dan nilai t hitung. 4,487 > 2,144, yang dapat dikatakan memberikan pengaruh.

3. Firm Size berpengaruh secara parsial terhadap profitabilitas pada perusahaan manufaktur sektor barang konsumsi yang terdaftar di Bursa Efek Indonesia periode 2017-2019. Sesuai pengujian t parsial menunjukkan nilai signifikansi $0,003<0,05$ dan nilai t hitung 4,838 > 2,144, yang dapat dikatakan memberikan pengaruh.

4. Kepemilikan Manajerial berpengaruh secara parsial terhadap profitabilitas pada perusahaan manufaktur sektor barang konsumsi yang terdaftar di Bursa Efek Indonesia 
periode 2017-2019. Sesuai pengujian t parsial menunjukkan nilai signifikansi $0,003<$ 0,05 , dan nilai t hitung 4,476>2,144, yang dapat dikatakan memberikan pengaruh.

Current Ratio,Debt To Equity,Firm Size,Kepemilikan Manajerial berpengaruh secara simultan terhadap profitabilitas pada perusahaan manufaktur sektor barang konsumsi yang terdaftar di Bursa Efek Indonwsia periode 2017-2019. Sesuai hasil uji F Simultan diketahui nilai signifikansi sebesar $0.004<0,05$ sehingga dari perbandingan pada uji signifikansi dapat dinyatakan hipotesa diterima.

\section{DAFTAR PUSTAKA}

Ariwiobowo, Handy,dkk. 2019. Mudah Memahami dan Mengimplementasikan Ekonom Makro. Yogyakarta : Andi.

Acemoglu, Daron, dkk. 2019. Macroeconomics. Jakarta : Erlangga.

Boedijoewono, Noegroho. 2020. Pengantar Statistika Ekonomi dan Bisnis. Edisi Keempat.

Boediono. 2014. Ekonomi Makro Seri Pengantar Ilmu Ekonomi. Cetakan Kedua puluh enam. Yogyakarta : BPFEE.

Brighan \& Houston. 2014. Dasar-Dasar dalam Manajemen Keuangan. Jakarta : Salemba Empat. Cetakan Pertama. Yogyakarta : UPP STIM YPKN.

Hery. 2020. Bank dan Lembaga Keuangan Lainnya. Jakarta : Grasindo.

Deviesa, Devie. 2019. Akuntansi Manajemen-Strategis dan Praktis. Yogyakarta : Andi.

Disman, H. 2018. Analisis Statistik dengan Model Persamaan Struktural (SEM) Teroritis dan Praktis. Bandung: Alfabeta.

Filbert, Ryan. 2019. Investor Blueprint. New Edition. Jakarta : Elex Komputindo

Haykal, Hassanain dan Johannes Ibrahim Kosasih. 2020. BANK dan LEASING Lembaga Keuangan Srategis dalam Praktik Bisnis di Indonesia. Cetakan Pertama. Bandung : Mandar

Hery. 2020. Financial Ratio For Business. Edisi Pertama. Cetakan Ketiga. Jakarta : Grasindo.

Kasmir. 2012. Analysis of Cash Flow. Jakarta : Rajawali Pers. Diskartes, Andhika. 2019. Take Profit. Jakarta : Elex Medis Komputindo.

Munawir, S., 2013. Analisa Laporan Keuangan, Liberty, Yogyakarta.

Samryn, L.N. 2019. Pengantar Akuntansi. Edisi Kedua. Cetakan Ketiga. Depok : Grafindo.

Susetyi, Budi. 2017. Statistika Untuk Analisis Data Penelitian. Edisi Kedua. Cetakan Keempat. Bandung:RefikaAditama.

Sunyoto. 2013. Analisis Cash Flow For Business. Cetakan Keenam Belas. Bandung : Centrer Of Academic Publishing Service (CAPS).

Suprapto, Hady. 2020. Penerapan Metodologi Penelitian dalam Karya Ilmiah. Cetakan Pertama. Yogyakarta: Gosyen Publishing.Maju.

Priyatno, Duwi, 2013. Olah Data Statistik dengan Program SPSS, MediaKom Yogyakarta. Santoso, Singgih, 2010. Metodologi Penelitian, BPFE, Yogyakarta. 